\title{
ЭВОЛЮЦИЯ СТРУКТУРЫ И ТЕКСТУРЫ В ПРОЦЕССЕ ХОЛОДНОЙ ДЕФОРМАЦИИ МЕТАСТАБИЛЬНОЙ АУСТЕНИТНОЙ СТАЛИ
}

\author{
(C) 2020 г. М. В. Однобокова ${ }^{a, ~ *, ~ А . ~ Н . ~ Б е л я к о в ~}{ }^{b}$, И. Н. Нугманов ${ }^{c}$, Р. О. Кайбышев \\ ${ }^{a}$ Институт физики перспективных материалов, Уфимский государственный авиационный \\ технический университет, ул. Карла Маркса, 12, Уфа, 450008 Россия \\ ${ }^{b}$ Белгородский государственный национальный исследовательский университет, \\ ул. Победы, 85, Белгород, 308015 Россия \\ ${ }^{c}$ Ташкентский государственный технический университет им. И. Каримова, \\ ул. Университетская, 2, Ташкент, 100123 Узбекистан \\ *e-mail: odnobokova_marina@mail.ru \\ Поступила в редакцию 27.12.2019 г. \\ После доработки 11.02.2020 г. \\ Принята к публикации 10.03.2020 г.
}

\begin{abstract}
Работа посвящена изучению эволюции структуры и текстуры в метастабильной аустенитной коррозионностойкой стали 03Х19H10 (в мас. \%: 0.05C-18.2Cr-8.8Ni-1.65Mn-0.43Si-0.05P-0.04S, основа $\mathrm{Fe}$ ) в процессе холодной прокатки, которая приводит к развитию двойникования и мартенситного превращения. Зарождение мартенсита деформации происходит гетерогенно в микрополосах сдвига и в местах их пересечения. Доля мартенсита деформации увеличивается с увеличением истинной деформации и приближается к $80 \%$ при $e=3$. Образование двойников деформации, микрополос сдвига и мартенситных кристаллов приводит к формированию однородной нанокристаллической структуры, состоящей из вытянутых $\gamma / \alpha^{\prime}-$ кристаллитов с поперечным размером около 100 нм, после большой деформации (e=2-3). Текстура аустенита после холодной прокатки характеризуется развитием сильных текстурных компонент Латунь $(\{110\}\langle 112\rangle)$ и Госс $(\{110\}\langle 001\rangle)$, тогда как текстура мартенсита деформации характеризуется сильной текстурной компонентой I* $(\{223\}\langle 110\rangle)$ и повышенной плотностью ориентаций вдоль $\gamma$-волокна (〈111 $\rangle \| \mathrm{HH})$. Ориентация межфазных $\gamma / \alpha^{\prime}-$-границ зависит от величины деформации.
\end{abstract}

Ключевые слова: аустенитная коррозионностойкая сталь, холодная прокатка, деформационное двойникование, мартенситное превращение, текстура деформации

DOI: $10.31857 / \mathrm{S} 0015323020070062$

\section{ВВЕДЕНИЕ}

В настоящее время актуальной задачей является разработка технологий получения полуфабрикатов из аустенитных хромоникелевых сталей, которые широко применяются в различных отраслях промышленности благодаря своим коррозионным свойствам, в высокопрочном состоянии [1-3]. Традиционная термическая обработка аустенитных хромоникелевых сталей включает нагрев до температуры $1000-1100^{\circ} \mathrm{C}$ и быстрое охлаждение, в результате такой обработки фиксируется $\gamma$-твердый раствор с гомогенным распределением легирующих элементов, в котором отсутствуют карбиды $\mathrm{M}_{23} \mathrm{C}_{6}$, что обеспечивает наилучшие коррозионные свойства $[1,4]$. Однако аустенитные хромоникелевые стали имеют низкую прочность после традиционной обработки на твердый раствор, что ограничивает возможность их примене- ния в качестве конструкционного материала. Интенсивная пластическая деформация аустенитных сталей позволяет существенно поднять их прочность как за счет получения ультрамелкозернистой (УМЗ) и нанокристаллической (НК) структуры, так и за счет образования мартенсита деформации [4-6]. Кинетика формирования таких структур в материалах с ГЦК-решеткой в значительной степени зависит от энергии дефектов упаковки (ЭДУ). Материалы с низкой ЭДУ (от 20 до 40 мДж/ ${ }^{2}$ ) характеризуются высокой скоростью структурной фрагментации за счет развития деформационного двойникования [7-9]. Деформационное двойникование приводит к формированию плотной пространственной сетки высокоугловых границ деформационного происхождения. Это, в свою очередь, обеспечивает повышение прочностных характеристик деформированного материала как за счет структурно- 
го упрочнения по механизму Холла-Петча, так и по механизму дислокационного упрочнения, поскольку максимальная плотность дислокаций возрастает в 5 и более раз с уменьшением размера кристаллитов от десятков мкм до 20-40 нм [9, 10].

Типичным представителем материала с низкой энергией дефекта упаковки ( 20 мДж/м $\left.{ }^{2}\right)$ является аустенитная коррозионностойкая хромоникелевая сталь 03X19H10 (AISI 304L) [6]. Стоит отметить, что аустенитные хромоникелевые стали являются метастабильными при комнатной температуре, поскольку температура начала фазового превращения $\gamma \rightarrow \alpha$ лежит в интервале $540-580^{\circ} \mathrm{C}$. Пластическая деформация при комнатной температуре метастабильных аустенитных сталей с такой величиной ЭДУ будет сопровождаться мартенситным превращением, которому способствует деформационное двойникование [1-3, 5, 7-9, 11-16]. Образование мартенсита деформации приводит к фрагментации структуры за счет формирования межфазных $\gamma / \alpha^{\prime}$-границ $[6,11-14]$. Известно, что образование мартенсита деформации протекает в соответствии с ориентационным соотношением Курдюмова-Закса или Нишиямы-Вассерманна, при котором формируются межфазные $\gamma / \alpha^{\prime}-г р а-$ ницы с разориентировкой в $45^{\circ}[11,15]$. Однако

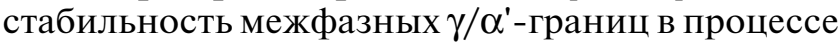
последующей деформации изучена недостаточно подробно [13]. Также остается неясной связь механизмов структурообразования с эволюцией текстуры в метастабильных аустенитных коррозионностойких сталях, холодная пластическая деформация которых сопровождается мартенситным превращением.

В зависимости от механизма пластической деформации в ГЦК-материалах различают два типа текстур: текстуру меди (\{112\} $>111\rangle$ и текстуру латуни $(\{011\}\langle 211\rangle)[6,17-19]$. Текстура меди наблюдается в металлах с высокой ЭДУ, где идет скольжение, а текстура латуни характерна для материалов с низкой ЭДУ, в которых основным механизмом пластической деформации является двойникование. Однако влияние образования мартенсита деформации на текстуру метастабильного аустенита недостаточно изучено. Таким образом, цель настоящей работы заключается в изучении закономерностей эволюции структуры и текстуры в аустенитной метастабильной коррозионностойкой стали 03Х19Н10 в процессе холодной прокатки до больших степеней деформации.

\section{МАТЕРИАЛ \\ И МЕТОДЫ ИССЛЕДОВАНИЙ}

Для проведения исследований использовали аустенитную коррозионностойкую сталь 03Х19Н10 следующего химического состава, \% (мас. \%): $0.05 \mathrm{C}-18.2 \mathrm{Cr}-8.8 \mathrm{Ni}-1.65 \mathrm{Mn}-0.43 \mathrm{Si}-0.05 \mathrm{P}-0.04 \mathrm{~S}$, остальное - Fe. Предварительная термомеханиче- ская обработка стали заключалась в горячей ковке и отжиге при $1100^{\circ} \mathrm{C}$ с последующим охлаждением в воду. Листовую прокатку образцов с исходным поперечным сечением $30 \times 30$ мм $^{2}$ проводили при комнатной температуре до истинных деформаций $e \approx 0.5 ; 1 ; 2$ и 3 . Структурные исследования выполняли с помощью просвечивающего электронного микроскопа (ПЭМ) Jeol JЕM-2100 и растрового электронного микроскопа Nova Nanosem 450, оснащенного детектором регистрации обратнорассеянных электронов (метод EBSD). Структурные исследования проводили в продольном сечении (перпендикулярном поперечному направлению прокатки) катаных образцов. Размер кристаллитов (зерен/субзерен) считали на изображениях, полученных с помощью ПЭМ, методом случайных секущих в направлении перпендикулярном направлению прокатки. По EBSD картам с помощью программного обеспечения TSL OIM Analysis строили функции распределения ориентировок (ФРО). Объемную долю мартенсита оценивали как среднее значение, полученное с помощью рентгеноструктурного анализа, ферритоскопа и метода EBSD.

\section{РЕЗУЛЬТАТЫ ИССЛЕДОВАНИЙ И ИХ ОБСУЖДЕНИЕ}

В результате предварительной обработки была получена исходная микроструктура со средним размером зерен 21 мкм $[6,15,17]$. Микроструктура аустенитной коррозионностойкой стали 03Х19Н10 после холодной прокатки показана на рис. 1. В процессе холодной прокатки до относительно небольшой истинной деформации $e=0.5$ происходит вытягивание исходных аустенитных зерен вдоль направления прокатки, а внутри зерен формируется сетка из субзеренных малоугловых границ (рис. 1а). Появление разориентированных субструктур связано с различием действующих систем скольжения в различных участках исходных зерен. Также на ранних стадиях пластической деформации развиваются деформационное двойникование и мартенситное $\gamma \rightarrow \alpha^{\prime}$-превращение. Двойникование приводит к дополнительной фрагментации аустенитных зерен за счет формирования когерентных границ $\Sigma 3$ с углом разориентировки около $60^{\circ}$. Мартенситное превращение приводит к формированию двухфазной структуры, состоящей из аустенитных и мартенситных зерен (рис. 1в), доля последних составила около 0.2 (рис. 2). Дальнейшая холодная прокатка до истинной деформации $e=2$ приводит к дополнительной фрагментации и формированию ультрамелкозернистой структуры, содержащей преимущественно высокоугловые границы (рис. 1б, 1г), а доля мартенситных зерен увеличилась до 0.65 (см. рис. 2). Образование мартенсита деформации также способствует фрагментации структуры за счет 

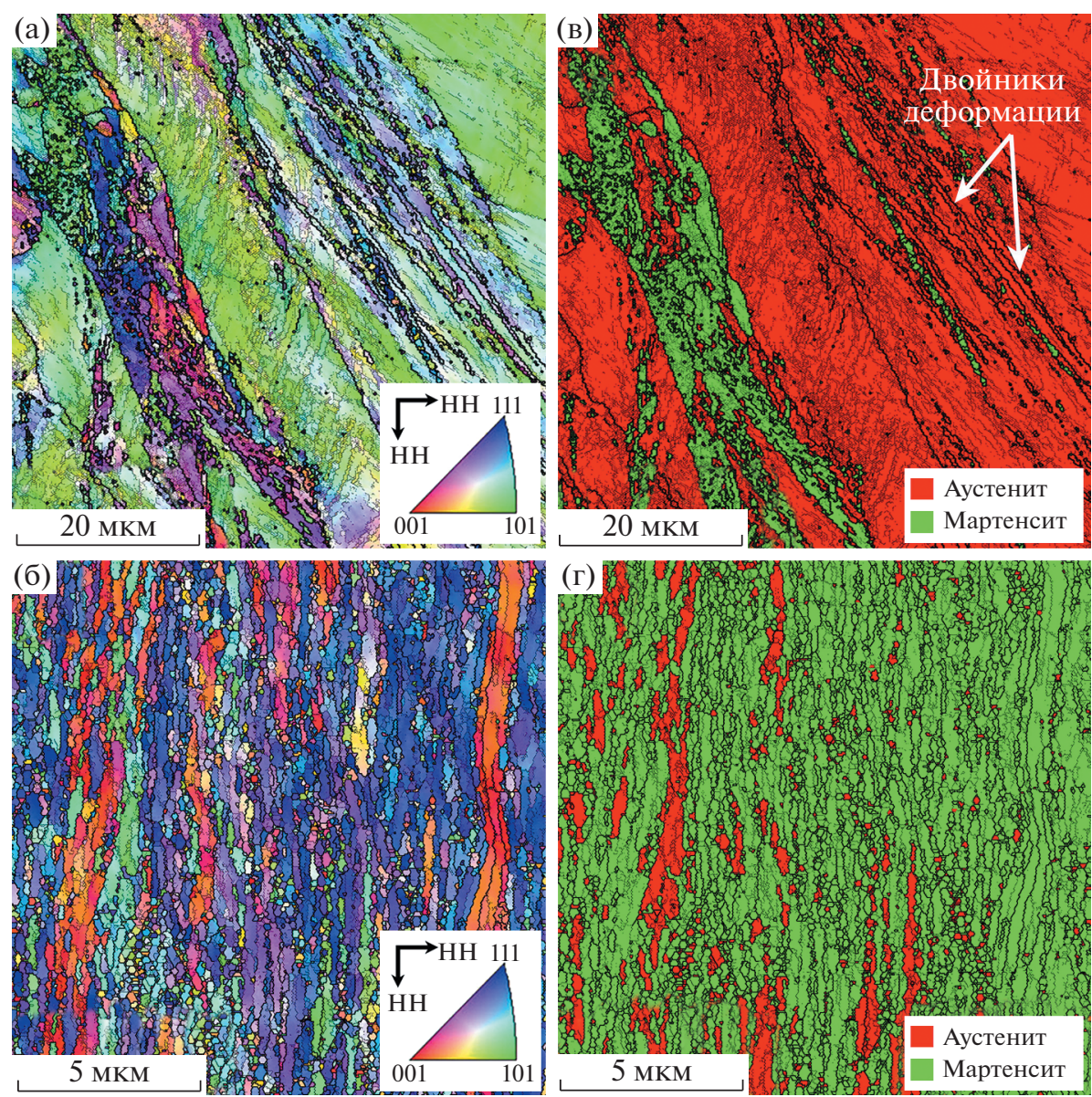

Рис. 1. Микроструктура (а, б) и фазовый состав (в, г) аустенитной коррозионностойкой стали 03Х19Н10 после холодной прокатки до истинных деформаций $e=0.5(\mathrm{a}, \mathrm{в})$ и $e=2(б$, г). Цвет на изображениях микроструктуры $(\mathrm{a}$, б) показывает кристаллографическое направление вдоль нормали к плоскости прокатки (HН).

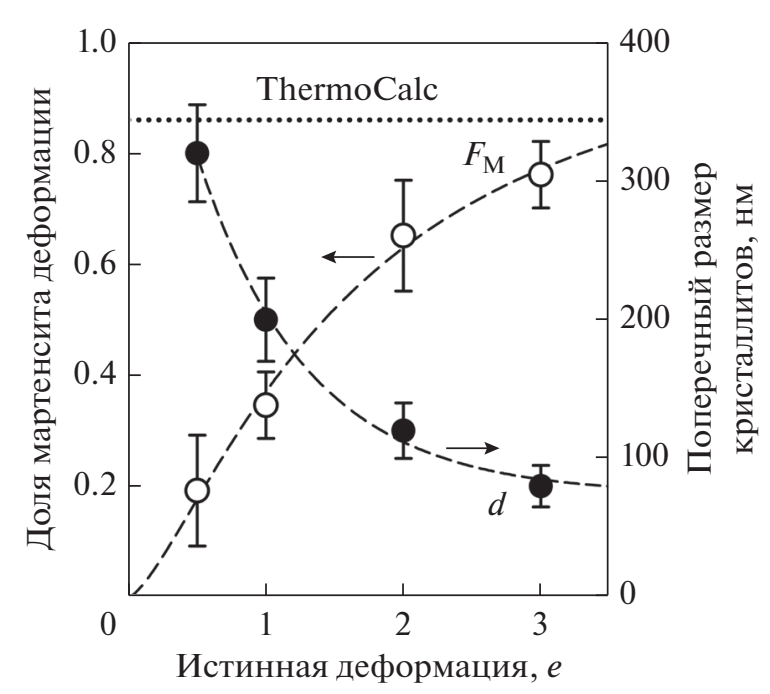

Рис. 2. Влияние истинной деформации (e) на долю мартенсита деформации $\left(F_{\mathrm{M}}\right)$ и поперечный размер кристаллитов $(d)$ в аустенитой коррозионностойкой стали 03Х19Н10.

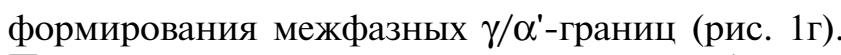
При дальнейшей прокатке до истинной деформации $e=3$ доля мартенсита деформации приближается к равновесному значению доли $\alpha$-феррита, рассчитанному с помощью программы ThermoCalc (см. рис. 2).

Тонкая структура аустенитной стали 03Х19Н10 после холодной прокатки до различных истинных деформаций показана на рис. 3. На рис. 3a видно, что на ранних стадиях холодной деформации в аустенитных зернах формируется высокая плотность деформационных двойников с плоскостью двойникования $\{111\}$, которые выглядят как тонкие пластины толщиной около 50 нм. Стоит отметить, что практически весь объем зерна заполнен нанодвойниковой структурой (центральная часть рис. 3a). В каждом зерне действует только одна система двойникования. Таким образом, исходные аустенитные зерна размером 21 мкм фрагментируются на пластины толщиной 50 нм, которые разделяются когерентными двойниковыми границами $\Sigma 3$. 

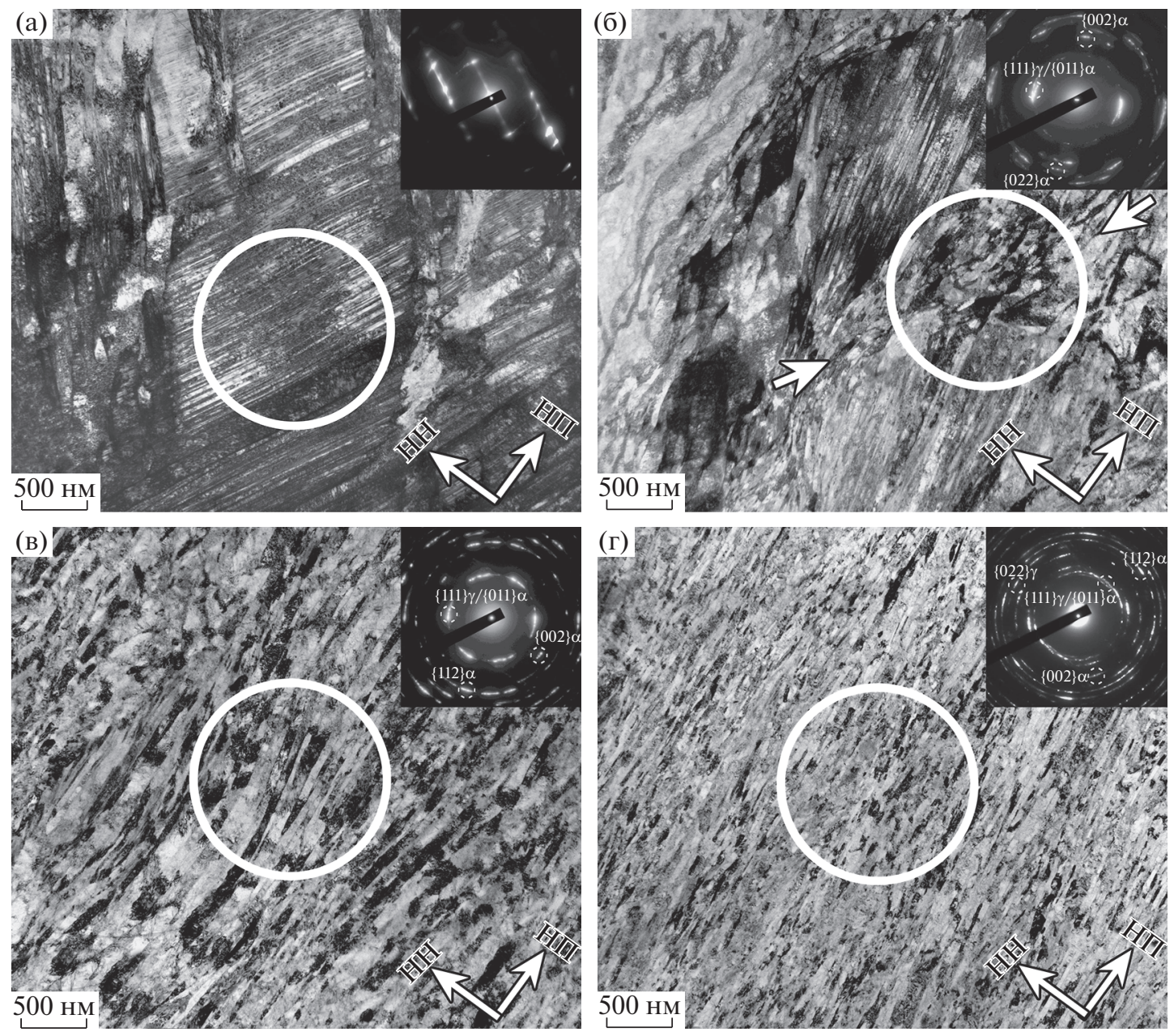

Рис. 3. Тонкая структура аустенитной коррозионностойкой стали 03 Х19Н10 после холодной прокатки до истинных деформаций $e=0.5$ (а), $e=1$ (б), $e=2$ (в) и $e=3$ (г). Окружности соответствуют участкам, с которых получены картины микро-дифракции.

Поскольку в стали 03Х19Н10 вторичное двойникование не развивается, то возможность пластической деформации по механизму двойникования исчерпывается. При $e=1$ локализация пластического течения происходит в виде образования микрополос сдвига [7, 8]. Микрополосы сдвига формируются под углом $30^{\circ}$ к направлению прокатки в пакетах нанодвойников (рис.3б). Микрополосы сдвига и их пересечения являются предпочтительными местами зарождения мартенсита деформации, их появление способствует росту доли мартенсита при промежуточных значениях деформации, а локализация пластического течения в микрополосах сдвига способствует дополнительной фрагментации структуры. Таким образом, микрополосы сдвига состоят из чередующихся слегка вытянутых $\gamma / \alpha$-кристаллитов с поперечным размером около 100 нм. В процессе последующей холодной прокатки до большой истинной деформации $(e=2$ и $e=3)$ границы между кристаллитами становятся более тонкими, разориентировка границ полос сдвига увеличивается, а разориентировка специальных границ, которые становятся некогерентными, сильно отклоняется от $60.4^{\circ}$, о чем свидетельствуют кольцевые электронограммы (рис. 3в, 3г). В результате образования микрополос сдвига и кристаллов мартенсита деформации происходит переход от двухмерной двойниковой наноструктуры к трехмерной структуре смешанного типа. Холодная прокатка до $e=3$ приводит к формированию структуры, состоящей из сильно вытянутых вдоль направления прокатки нанокристаллитов аустенита и мартенсита с поперечным размером около $80 \mathrm{HM}$.

На рис. 4 показано распределение межфазных

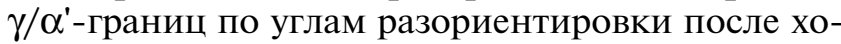
лодной прокатки стали 03Х19Н10. Распределение межфазных $\gamma / \alpha^{\prime}$-границ зерен по углам разориентировки характеризуется одним отличительным пиком, который соответствуют углам около $45^{\circ}$. Данный пик связан с протеканием деформацион- 
(a)

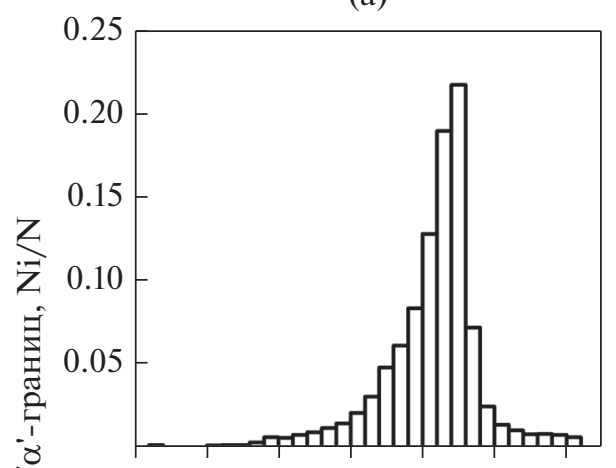

(б)

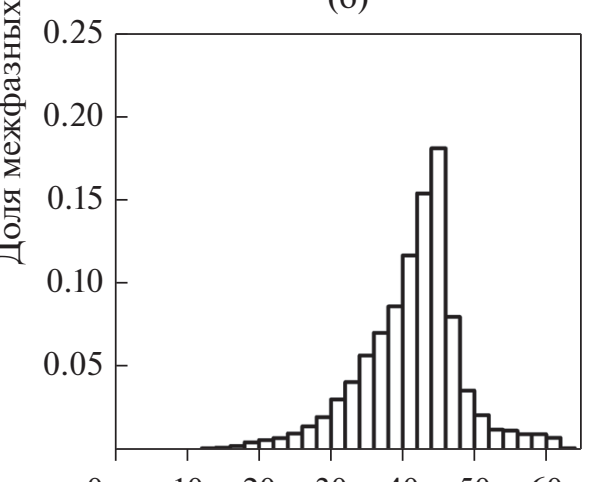

(B)

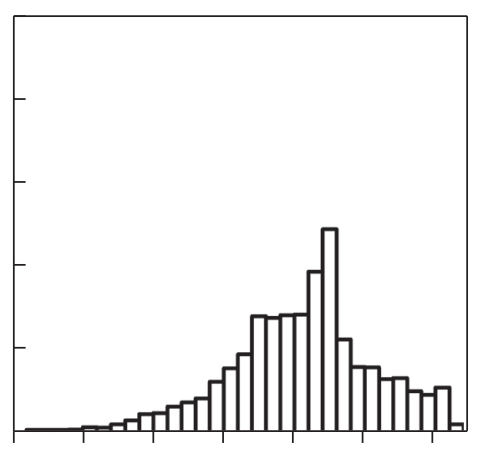

(г)

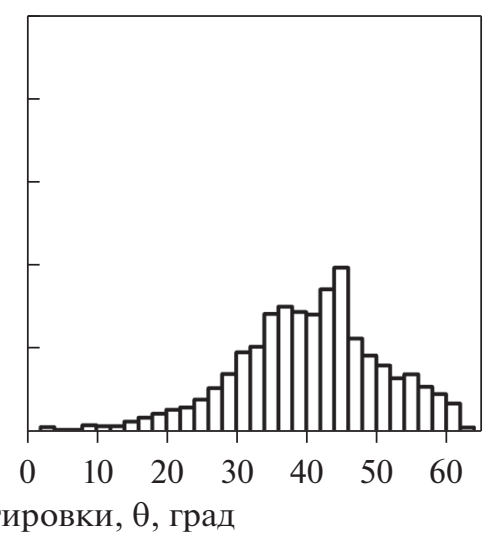

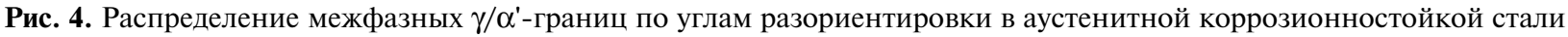
03Х19Н10 после холодной прокатки до истинных деформаций $e=0.5$ (a), $e=1$ (б), $e=2$ (в) и $e=3$ (г).

ного мартенситного превращения по сдвиговому механизму, так как ориентационные соотношения между аустенитом и мартенситом в коррозионностойких сталях близки к соотношениям Курдюмова-Закса и Нишиямы-Вассермана, которые приводят к разориентировке между $\gamma$ и $\alpha$-фазой на $42.9^{\circ}$ и $46^{\circ}$, соответственно [11, 15]. При относительно небольших истинных деформациях $e=0.5$ и $e=$ $=1$ пик, соответствующий углам около $45^{\circ}$, является острым (рис. 4а, 4б), так как при этих деформациях в основном происходит появление новых мартенситных зерен. Стоит отметить, что максимальная доля межфазных границ соответствует углу разориентировки $46^{\circ}$, т.е. преимущественно между аустенитными и мартенситными зернами выполняется ориентационное соотношение Нишиямы-Вассермана $[11,15]$. Последующая холодная прокатка до истинных деформаций $e=2$ и $e=3$ приводит не только к появлению новых мартенситных кристаллов, так как доля мартенсита деформации постепенно увеличивается во всем диапазоне истинных деформаций, но и к переориентации ранее сформированных межфазных

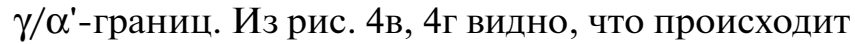
размытие пика, соответствующего углам около $45^{\circ}$, в сторону межфазных границ с разориенти- ровкой около $35^{\circ}$. Таким образом, в процессе деформации происходит переориентация межфазных

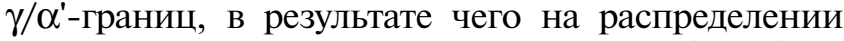
формируются два пика для углов около $35^{\circ}$ и $45^{\circ}$.

На рис. 5а приведено схематическое представление ФРО основных текстурных компонент для аустенита и мартенсита, а их Эйлеровские координаты приведены в табл. 1. ФРО аустенитной стали 03Х19Н10 после холодной прокатки до различных истинных деформаций приведены на рис. 5б. После холодной прокатки текстура аустенита характеризуется формированием повышенной плотности ориентаций вдоль $\zeta$-волокна $(\langle 110\rangle \| \mathrm{HH})$ и

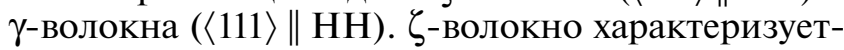
ся двумя отличительными максимумами интенсивностей вблизи текстурной компоненты Латунь $(\{110\}\langle 112\rangle)$ и текстурной компоненты Госс $(\{110\}\langle 001\rangle)$, которые характерны для катанных ГЦК-материалов с низкой или средней энергией дефекта упаковки, склонных к деформационному двойникованию и формированию полос сдвига. Таким образом, Ц-волокно появляется в текстуре аустенита при относительно небольших деформациях и усиливается с увеличением истинной деформации. Стоит отметить, что доля текстурной компоненты Латунь превалирует над долей тек- 
(a)

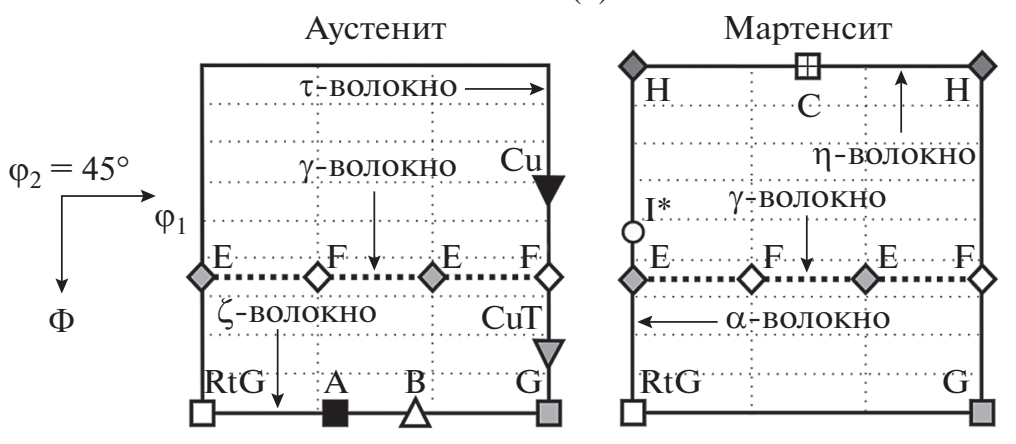

(б)

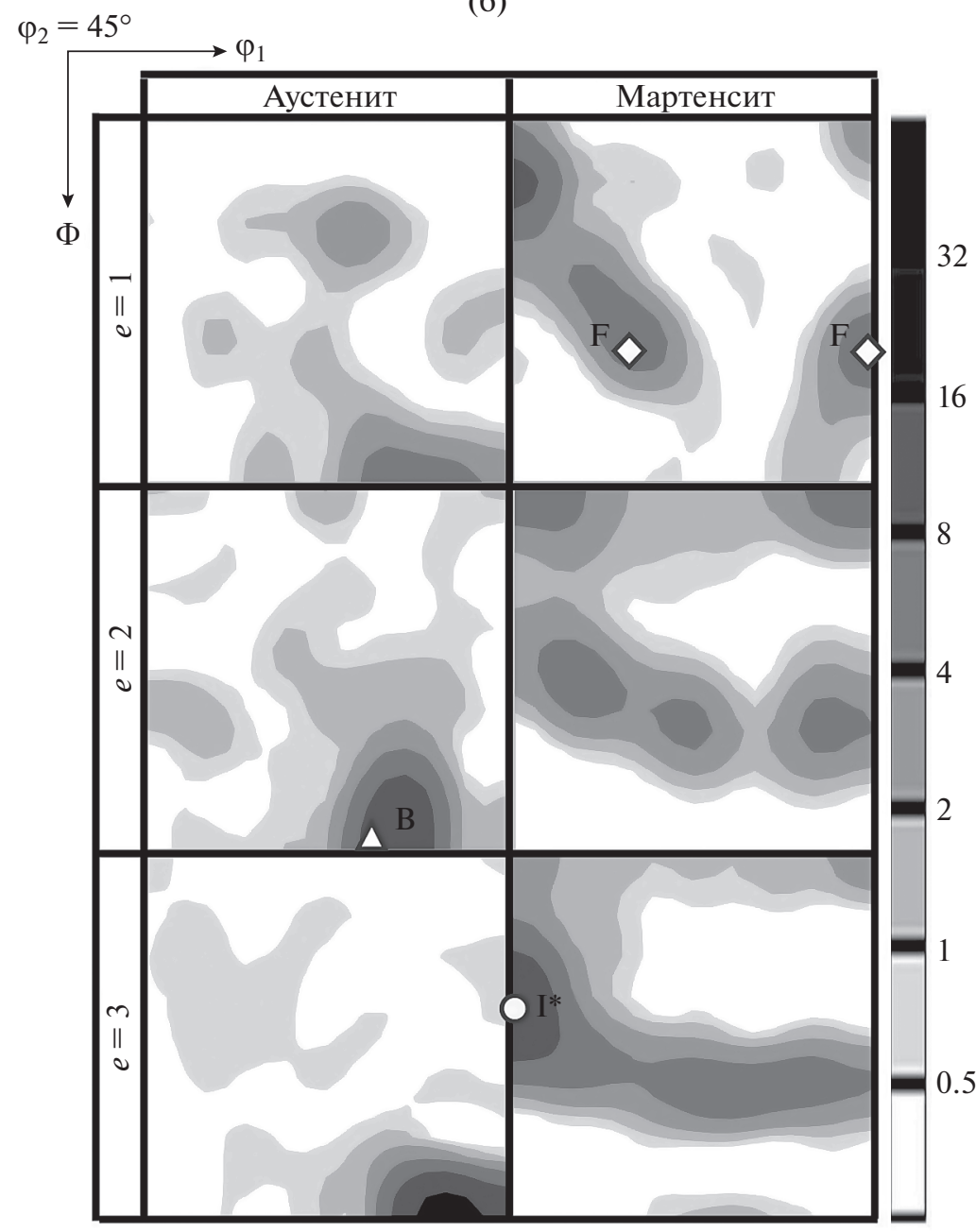

Рис. 5. Схематическое представление ФРО основных текстурных компонент для аустенита и мартенсита (а) и ФРО аустенитной коррозионностойкой стали 03Х19Н10 после холодной прокатки до различных истинных деформаций (б).

стурной компоненты Госс во всем диапазоне рассматриваемых деформаций [6]. Образование $\gamma$-волокна с максимумами интенсивностей, которые соответствуют текстурным компонентам Е $(\{111\}$ $\langle 110\rangle)$ и $\mathrm{F}(\{111\}\langle 112\rangle)$, связано с формированием ультрамелких зерен в полосах сдвига. $\gamma$-Волокно формируется при промежуточных деформациях от $e=1$ до $e=2$, а с увеличением истинной деформации, когда происходит переориентация кристаллитов внутри ранее сформированных полос сдвига - ослабляется. Кроме того, ослабление текстурных компонент Е и F может быть связано с протеканием мартенситного превращения, которое легко развивается в микрополосах сдвига, а, 
Таблица 1. Текстурные компоненты типичные для аустенита и мартенсита

\begin{tabular}{|c|c|c|c|c|}
\hline \multirow{2}{*}{ Компонента, символ } & \multirow{2}{*}{$h k l$}$\langle u v w\rangle$ & \multicolumn{3}{|c|}{ Углы Эйлера } \\
\hline & & $\varphi_{1}$ & $\Phi$ & $\varphi_{2}$ \\
\hline Куб (C) & $\{001\}\langle 100\rangle$ & 45 & 0 & 45 \\
\hline Повернутый куб (Н) & $\{001\}\langle 110\rangle$ & $0 / 90$ & 0 & 45 \\
\hline $\mathrm{E}$ & $\{111\}\langle 110\rangle$ & $0 / 60$ & 55 & 45 \\
\hline $\mathrm{F}$ & $\{111\}\langle 112\rangle$ & $30 / 90$ & 55 & 45 \\
\hline$I^{*}$ & $\{223\}\langle 110\rangle$ & 0 & 43 & 45 \\
\hline Гocc $(\mathrm{G})$ & $\{110\}\langle 001\rangle$ & 90 & 90 & 45 \\
\hline Повернутый Госс (RtG) & $\{110\}\langle 110\rangle$ & 0 & 90 & 45 \\
\hline Латунь (В) & $\{110\}\langle 112\rangle$ & 55 & 90 & 45 \\
\hline A & $\{110\}\langle 111\rangle$ & 35 & 90 & 45 \\
\hline Медь $(\mathrm{Cu})$ & $\{112\}\langle 111\rangle$ & 90 & 35 & 45 \\
\hline
\end{tabular}

следовательно, приводит к уменьшению в аустените доли ориентаций, связанных с микрополосами сдвига.

После холодной прокатки текстура мартенсита деформации характеризуется развитием ฤ-волокна $(\langle 001\rangle \| \mathrm{HH})$ и $\gamma$-волокна $(\langle 111\rangle \| \mathrm{HH})$. $\eta$-волокно с максимумами интенсивностей вблизи текстурной компоненты Н $(\{001\}\langle 110\rangle)$ усиливается при $e=2$ и сохраняется при $e=3$. $\gamma$-волокно характеризуется повышенной плотностью ориентаций вблизи текстурной компоненты F (\{111\} $\langle 112\rangle)$ при относительно небольшой истинной деформации $e=1$. Формирование текстурной компоненты F в текстуре мартенсита на ранних ста-

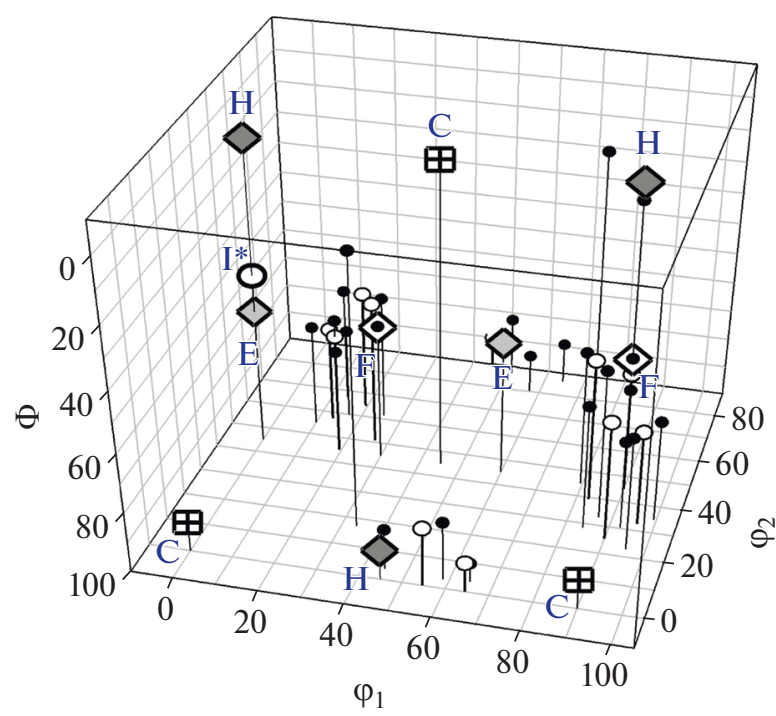

Рис.6. Ориентация мартенсита, полученная в результате трансформации аустенита с ориентировкой компоненты Латунь $\{110\}\langle 112\rangle$ по ориентационным соотношениям Курдюмова-Закса (черные символы) и НишиямыВассермана (белые символы). диях пластической деформации связано с протеканием сдвигового фазового $\gamma \rightarrow \alpha^{\prime}$-превращения по ориентационным соотношениям Курдюмова-Закса и Нишиямы-Вассермана, в результате трансформации аустенита с ориентировкой текстурной компоненты Латунь (рис. 6) [6]. Увеличение истинной деформации приводит К выравниванию плотности ориентаций вдоль всего $\gamma$-волокна. Стоит отметить, что после большой истинной деформации $e=3$, мартенсит деформации характеризуется сильной текстурной компонентой I* $(\{223\}\langle 110\rangle)$, которая обычно связана с основной системой скольжения типа $\{110\}\langle 111\rangle$ в ОЦК-металлах. Текстурная компонента I* является более стабильной, чем текстурная компонента F, что дополнительно подтверждает переориентацию межфазных $\gamma / \alpha^{\prime}-$ границ (полученных в результате сдвигового мартенситного превращения) в процессе деформации. Разориентировка между мартенситом и аустенитом для ориентаций I* и Латунь, соответственно, составляет $31^{\circ}$, а для I* и Госс $-45^{\circ}$. Таким образом, формирование текстурной компоненты I* приводит к появлению двух характерных пиков на распределении межфазных границ по углам разориентировки.

\section{Выводы}

Холодная прокатка аустенитной коррозионностойкой стали 03Х19Н10 сопровождается деформационным двойникованием и образованием мартенсита деформации, что способствуют быстрой фрагментации микроструктуры. Формирование микрополос сдвига при промежуточных значениях деформации способствует протеканию деформационного мартенситного превращения и, как следствие, увеличению объемной доли мартенсита. Мартенситное превращение протекает в соответствии с ориентационными соотношениями Курдюмова-Закса и Нишиямы-Вассер- 
мана, что подтверждается формированием меж-

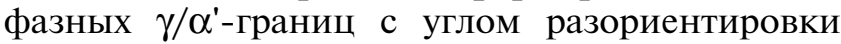
около $45^{\circ}$. Большая доля межфазных $\gamma / \alpha^{\prime}$-границ имеет разориентировку $46^{\circ}$, т.е. образование мартенсита деформации преимущественно идет по ориентационному соотношению Нишиямы-Вассермана. С увеличением истинной деформации происходит переориентация аустенитных и мартенситных кристаллитов, в результате чего межфазные $\gamma / \alpha^{\prime}$-границы стремятся к более стабильной ориентации с разориентировкой в $35^{\circ}$. Нанокристаллическая структура, состоящая из сильновытянутых аустенитных и мартенситных зерен/субзерен с поперечным размером около 80 нм, формируется в процессе холодной прокатки до $e=3$. Эволюция текстуры аустенита в процессе холодной прокатки связана с усилением текстурных компонент Латунь $(\{110\}\langle 112\rangle)$ и Госс $(\{110\}\langle 001\rangle)$, образующих $\zeta$-волокно $(\langle 110\rangle \| \mathrm{HH})$. При промежуточных значениях деформации текстура мартенсита характеризуется формированием сильной текстурной компоненты F $(\{111\}\langle 112\rangle)$, появлению которой способствует протекание фазового $\gamma \rightarrow \alpha^{\prime}$-превращения по ориентационным соотношениям Курдюмова-Закса и Нишиямы-Вассермана. С увеличением истинной деформации в текстуре мартенсита усиливается текстурная компонента I* $(\{223\}\langle 110\rangle)$, что указывает на ее более стабильную ориентацию и, как следствие, на переориентацию межфазных $\gamma / \alpha^{\prime}$-границ, образованных в результате сдвигового механизма мартенситного превращения.

Исследование выполнено при финансовой поддержке РФФИ в рамках научного проекта № 19-38-60047.

\section{СПИСОК ЛИТЕРАТУРЫ}

1. Lo K.H., Shek C.H., Lai J. Recent developments in stainless steels // Mater. Sci. Eng. R. 2009. V. 65. № 4. P. 39-104.

2. Макаров А.В., Скорынина П.А., Волкова Е.Г., Осинцева A.Л. Влияние нагрева на структуру, фазовый состав и микромеханические свойства метастабильной аустенитной стали, упрочненной наноструктурирующей фрикционной обработкой // ФММ. 2018. Т. 119. № 12. C. 1257-1264.

3. Макаров А.В., Коршунов Л.Г. Металлофизические основы наноструктурирующей фрикционной обработки сталей // ФММ. 2019. Т. 120. № 3. С. 327-336.

4. Сагарадзе В.В., Уваров А.И. Упрочнение аустенитных сталей. М.: Наука, 1989. 270 с.

5. Сагарадзе В.В., Уваров А.И. Упрочнение и свойства аустенитных сталей. Екатеринбург: РИО УрО PAH, 2013. $718 \mathrm{c}$.
6. Odnobokova M., Belyakov A., Kaibyshev R. Grain refinement and strengthening of austenitic stainless steels during large strain cold rolling // Phil. Mag. 2019. V. 99. № 5. P. 531-556.

7. Sakai T., Belyakov A., Kaibyshev R., Miura H., Jonas J.J. Dynamic and post-dynamic recrystallization under hot, cold and severe plastic deformation conditions // Progr. Mater. Sci. 2014. V.60. № 1. P.130-207.

8. Kusakin P.S., Kaibyshev R.O. High-Mn twinning-induced plasticity steels: microstructure and mechanical properties // Rev. Adv. Mater. Sci. 2016. V. 44. № 4. P. 326-360.

9. Yanushkevich Z., Belyakov A., Haase C., Molodov D.A., Kaibyshev R. Structural/textural changes and strengthening of an advanced high-Mn steel subjected to cold rolling // Mater. Sci. Eng. A. 2016. V. 651. P. 763-773.

10. Karavaeva M.V., Abramova M.M., Enikeev N.A., Raab G.I., Valiev R.Z. Superior strength of austenitic steel produced by combined processing, including equal-channel angular pressing and rolling // Metals. 2016. V. 6. № 12. P. 310.

11. Nakada N., Ito H., Matsuoka Y., Tsuchiyama T., Takaki S. Deformation-induced martensitic transformation behavior in cold-rolled and cold-drawn type 316 stainless steels // Acta Mater. 2010. V. 58. № 3. P. 895-903.

12. Косицына И.И., Сагарадзе В.В. Фазовые превращения и механические свойства нержавеющей стали в наноструктурном состоянии // Изв. РАН. 2007. T. 71. № 2. С. 293-296.

13. Литовченко И.Ю., Тюменцев А.Н., Шевченко Н.В., Корзников А.В. Эволюция структурно-фазовых состояний при больших пластических деформациях аустенитной стали 17Cr 14Ni 2Mo // ФММ. 2011. T. 112. № 4. C.436-448.

14. Tyumentsev A.N., Litovchenko I.Y. Models of dislocation formation and mechanical twinning by local reversible martensitic transformations in FCC nanocrystals // Adv. Mater. Res. 2014. V. 1013. P. 234-241.

15. Odnobokova M., Belyakov A., Kaibyshev R. Development of nanocrystalline $304 \mathrm{~L}$ stainless steel by large strain cold working // Metals. 2015. V. 5. P. 656-668.

16. Kraposhin V., Jakovleva I., Karkina L., Nuzhny G., Zubkova T., Talis A. Microtwinning as a common mechanism for the martensitic and pearlitic transformations // J. Alloys Compd. 2013. V. 577S. P. 30-36.

17. Odnobokova M.V., Belyakov A.N. Effect of Cold Rolling and Subsequent Annealing on the Microstructure and the Microtexture of Austenitic Corrosion-Resistant Steels // Rus. Met. (Metally). 2019. V. 2019. № 4. P. 315-325.

18. Горелик С.С., Добаткин С.В., Капуткина Л.М. Рекристаллизация металлов и сплавов. М.: МИСиС, 2005. $432 \mathrm{c}$.

19. Leffers T., Ray R.K. The brass-type texture and its deviation from the copper-type texture // Progr. Mater. Sci. 2009. V. 54. № 3. P. 351-396. 